\title{
Wages and Unemployment across Business Cycles: A High-Frequency Investigation
}

\author{
Lei Fang and Pedro Silos
}

\section{Working Paper 2012-16 October 2012}

\begin{abstract}
This paper investigates the change in wages associated with a spell of unemployment. The novelty lies in using monthly data from the Survey of Income and Program Participation (SIPP) to analyze the dynamics of those wage changes across different business cycles. The level of education or the sector of re-employment affects the change in wages following an unemployment spell differently across different downturns. The degree of wage rigidity varies across recessions; wage changes preand post-unemployment are sometimes procyclical and sometimes countercyclical. These results may be useful for understanding the different aggregate employment dynamics observed across downturns and recoveries.
\end{abstract}

JEL classification: E24, J31

Key words: wage rigidity, unemployment duration, jobless recoveries

The authors thank Jing Xu for excellent research assistance, Bruce Fallick for a thoughtful discussion on an earlier draft, and Shigeru Fujita for a helpful conversation. The views expressed here are the authors' and not necessarily those of the Federal Reserve Bank of Atlanta or the Federal Reserve System. Any remaining errors are the authors' responsibility.

Please address questions regarding content to Lei Fang, Research Department, Federal Reserve Bank of Atlanta, 1000 Peachtree Street, N.E., Atlanta, GA 30309-4470, 404-498-8057, lei.fang@atl.frb.org, or Pedro Silos, Research Department, Federal Reserve Bank of Atlanta, 1000 Peachtree Street, N.E., Atlanta, GA 30309-4470, 404-498-8630, psilos@frbatlanta.org.

Federal Reserve Bank of Atlanta working papers, including revised versions, are available on the Atlanta Fed's website at frbatlanta.org/pubs/WP/. Use the WebScriber Service at frbatlanta.org to receive e-mail notifications about new papers. 


\section{Introduction}

When it comes to employment dynamics, not all recessions look alike. Some display large drops in employment followed by swift recoveries, yet after other recessions labor markets remain weak with low growth in job creation long after output begins to increase. The behavior of labor productivity also changes across recessions. It is procyclical during some periods and countercyclical during other periods.

In light of this heterogeneity in aggregate labor market dynamics, it seems sensible to investigate more disaggregated patterns and compare these across recessions. The literature has focused on quantities (worker and job flows) but our knowledge of how individual wages evolve across recessions is limited. To remediate this deficiency, this paper investigates whether the dynamics and determinants of wage changes associated with a spell of unemployment vary across business cycles. Are unemployment spells more damaging to highly-educated individuals during specific downturns? Do wages earned upon re-employment react more to aggregate labor market conditions in particular recessions? These are examples of the questions this paper answers. To be more specific we examine individual-level wages along three dimensions. First, we analyze, by recession, the distribution of individual wage changes pre- and postunemployment for spells of different length. Second, we examine, also by recession, how those wage changes relate to workers' characteristics. Finally, we compare the degree of nominal wage rigidity across recessions. By rigidity we refer to the reaction of the change in wages pre- and post-unemployment to changes in aggregate labor market conditions. Restricting our attention to wage changes after an unemployment spell is predicated on previous research. Studies using wage data at the annual frequency have found that wages of workers who do not switch jobs vary little over time. ${ }^{1}$

All of our analysis is based on the Survey of Income and Program Participation

\footnotetext{
${ }^{1}$ See Pissarides (2010) for a summary of results regarding cyclical dynamics of wages and more evidence that wages of "switchers" are more cyclical than those of job "stayers". The term "switchers" in previous literature refers to workers who switch employers without necessarily suffering a spell of unemployment. Here we refer to workers who, in addition to changing jobs, also experience an intervening spell of unemployment.
} 
(SIPP). This survey provides labor-market-related information at the monthly frequency for a large panel of individuals. Available data allow us to compare the last three recessions: 1991, 2001, and 2008. It is both the high-frequency and the panel length - about three years for each survey - that make our analysis feasible. Since unemployment is a short-lived phenomenon for most individuals, information at the monthly frequency is essential for comparing wages before and after unemployment. Our analysis concerns only a particular group of workers: those who are paid by the hour. The focus on these workers is most appropriate because they provide a clean measure of the price of labor. Measurement errors in hours that plague total earnings responses frequently contaminate wages computed for salaried workers.

We find the distributions of wage changes after long and short unemployment spells to be similar. Of the three recessions we study, only during the Great Recession were the average growth rate in wages higher for the short-term unemployed than the long-term unemployed. During the 1991 and 2001 recessions the growth in wages after an unemployment spell was higher for the long-term unemployed. ${ }^{2}$ We find that about $50 \%$ of all unemployed (both short- and long-term) individuals experience an increase in wage. The picture of the long-term unemployed as expecting large drops in wages is only half-true: typically a large mass of them enjoy fairly large wage changes. The so-called Great Recession was an exception: the distribution of wage changes features clearly a decrease in the mass of long-term unemployed that experience large and positive wage growth, relative to 1991 and 2008. However, a stylized fact across all recessions we study is that the distribution of wage changes for the long-term unemployed displays positive skewness while skewness is negative for the short-term unemployed. Finally, it is worth noting that the degree of dispersion in wage changes

\footnotetext{
${ }^{2}$ In this paper, long-term spells are those that last more than four months. The reason for setting that cut-off point for a long-term spell is a result of the design in the SIPP. As interviews occur every four months, and there is a tendency in some respondents to provide the same answer in each for the months in between interviews, lengths of unemployment spells cluster at every four months. During the 1991 recessions the number of workers unemployed for more than 8 months is small. Hence, we settle for 4 months as the cut-off length for defining long-term.
} 
is always larger for the long-term unemployed.

The association between wage changes and certain workers' characteristics changes from recession to recession. Education provides one of the most interesting examples. The relationship between education and wage changes is U-shaped during the 1991 recession. In other words, workers with high and low education levels experience lower wage drops as a result of being unemployed, relative to workers with medium education levels. This pattern disappears during the 2001 recession, which saw larger wage drops for workers with a higher level of education. ${ }^{3}$ That relationship reverses and the 2008 recession sees smaller drops as the education level rises. Moreover, these patterns hold for long-term and short-term spells. The relationship between the magnitude of wage changes and inter-industry transitions also differs across downturns. Workers who changed industries after an unemployment spell during the 1991 recession experienced small changes in wages. By contrast, wage changes in 2001 and 2008 were large in absolute value, and not all negative. For example, the construction industry was not hit hard during 2001, but workers who lost their job in construction and found employment in an alternative industry after an unemployment spell saw wages drop by $14 \%$. During 2008 that number was 20\% and in 1991 only 2\%. These findings support the view that 2001 and 2008 were recessions with a large degree of structural change. Other variables affect wages in a comparable manner across downturns. The negative effect of age on wages after an unemployment spell has been roughly constant over the past three recessions.

The final question we investigate concerns the degree of nominal wage rigidity across downturns. In widely used models (e.g. Pissarides (1985)), this hypothesis can generate large drops in employment followed by slow recoveries in the labor market. Some authors, most notably Shimer (2010), have put forth the hypothesis that wages have recently become more rigid, potentially explaining the prevalence of recoveries

\footnotetext{
${ }^{3}$ These statements are conditional on other worker characteristics such as ethnicity or marital status.
} 
with meager employment growth. ${ }^{4}$ We empirically assess this potential explanation. We find that from the point of view of the cyclical reaction of wages to changes in the unemployment rate, the 2008 recession looks more like the 1991 than the 2001 recession. Wages were procyclical, casting doubt on the hypothesis that rigid wages have been a factor amplifying the drop in employment and the slow job growth in the aftermath of the 2008 recession. On the other hand, they may have contributed to the jobless recovery experienced after the 2001 recession. The methodology we employ to examine the dynamics of pre- and post-unemployment wage changes follows previous analyses, for instance, Barsky, Solon, and Parker (1994) and Deveraux (2001), but we apply that methodology to high-frequency data instead of annual data. ${ }^{5}$

A comparative analysis of recessions focusing on the behavior of wage changes preand post-unemployment is new to the literature. We begin by describing the distribution of wage changes following an unemployment spell, distinguishing between shortterm and long-term spells. Contrary to studies which focused on displaced workers (e.g. Jacobson, LaLonde, and Sullivan (1991) or Portugal (1989)), we find that the difference between wage changes of short- and long-term unemployed is not large. There are major differences between those studies and ours that could explain the discrepancies. First, the time periods are different ${ }^{6}$ implying important changes in the composition of the labor force or even a different nature of the 1980s recessions relative to the more recent ones we study. Second, workers in our sample may return to their previous employer; displaced workers by definition are re-employed elsewhere. As job-specific human capital is still useful if the employer remains the same, wage changes may not be substantial. Finally, our definition of long-term unemployment

\footnotetext{
${ }^{4}$ Wage rigidity as a mechanism to generate volatile unemployment rates has been explored extensively, for instance in Shimer (2004).

${ }^{5}$ We focus on nominal wages instead of real wages which are actually the appropriate measure in the theoretical work. Nevertheless, inflation measures have been rather stable during the short-time periods considered and relative to past history (e.g. the 1970s).

${ }^{6}$ Portugal (1989) studies the Displaced Workers Special survey (DWS) from the CPS conducted in 1984. Jacobson, LaLonde, and Sullivan (1991), study quarterly earnings from 1974 to 1986 for a group of workers in Pennsylvania.
} 
is a spell that lasts for more than four months (16 weeks), which is a relatively short period of time.

The cyclical dynamics of wages have been the object of a large literature. ${ }^{7}$ However, since previous studies have used annual data a comparison of wage rigidity across recessions has eluded economists. Employing the high-frequency data in SIPP allows us to examine the relationship between wage changes and the unemployment rate across recessions. To the best of our knowledge, ours is the first paper with that goal.

A recent study by Barattieri, Basu, and Gottschalk (2010) is closest to what we attempt here. There are similarities such as the use of the SIPP (only the 1996-1999 panel), and the focus on nominal wage changes, but the similarities end there. Their interest lies in assessing the frequency of wage changes for workers who do not change jobs. They show that the distribution of wage changes is right-skewed with little mass on the left side, arguing that there is a substantial amount of wage rigidity. We study the wage changes after unemployment spells and whether these wage changes are cyclical. ${ }^{8}$ Moreover, we compare the cyclical dynamics across downturns and subsequent recoveries, arguably when movements in the unemployment (and other variables related to the business cycle) are largest. During downturns and the early phases of the recovery, the distribution of wage changes unemployed workers experience displays little skewness; and although the median is zero change, there is a substantial mass of workers who experience large wage drops, both short and long-term unemployed.

\section{Wage Dynamics and Unemployment}

\footnotetext{
${ }^{7} \mathrm{~A}$ non-exhaustive list of examples in this literature includes Barlevy (2001), Bils (1985), Barsky, Solon, and Parker (1994), Deveraux (2001), and Shin (1994).

${ }^{8}$ In the Appendix we analyze the 1996-1996 and 2004-2007 surveys. We confirm that wages changes pre- and post-unemployment do not react much to aggregate labor market conditions, thus obtaining similar results to Barattieri et al. for our sample of unemployment spells.
} 


\subsection{The SIPP}

The SIPP is a longitudinal survey designed to be representative of the U.S. labor force. It is constructed as a sequence of panels of households who are interviewed for about three years but the actual time-frame differs across panels. Designed and maintained by the U.S. Census, the first panel began in 1984 and the last panel started in 2008. Households are interviewed every four months during the time they remain in the sample, providing information on work experience (employment, hours, earnings, occupation, and industry, among other variables) for the months in between interviews. The SIPP also requests useful information for analyzing labor market outcomes such as gender, age, education, marital status, and ethnicity.

The introduction motivates a comparative analysis of business cycles based on the dynamics of individual wages. To perform this analysis we need to define first what we mean by a "business cycle". In the United States an official recession begins whenever the National Bureau of Economic Research (NBER) determines that a peak in economic activity has been reached, and it lasts until a similar announcement is made regarding the trough. In general a business cycle lasts until another peak is reached. Given the length of the typical survey in the SIPP - about three years - and to be consistent in our comparison of business cycles, the definition of a cycle we employ is somewhat different. The starting point of a business cycle is the official NBER-announced peak, or the peak in employment, whichever occurs earlier. Clearly if the SIPP survey starts after any of those two peaks, that will be the starting point of the business cycle. The final point of a cycle is the recovery of employment ${ }^{9}$ levels to the same level of its previous peak, or the end of the SIPP panel, whichever occurs earlier. Hence the official peaks for the 1990, 2001, and 2008 recessions are July 1990, March 2001, and December 2007. The peaks in employment are March 1990, December 2000, and January 2008. Since the three panels of the SIPP begin in October 1990, October 2000, and May 2008,

\footnotetext{
${ }^{9}$ Payroll employment in private industries as released by the Bureau of Labor Statistics.
} 
the starting points of the three cycles are October 1990, December 2000, and May 2008. The end points are July 1993, December 2003, and July 2010. The periods capture most of the downturn in all three cases and the initial phases of the recovery. We refer to each of these three episodes as a recessionary episode, and we label them throughout by the reference years 1991, 2001, and 2008. ${ }^{10}$

For each of these recessionary episodes we restrict the analysis to hourly workers. This group represents about $44.6 \%$ of all workers in 1991, 50.6\% of all workers in 2001, and $49.1 \%$ of all workers in 2008 . The reason to focus on this group is that they provide the cleanest measure of the price of labor: a wage rate for each hour they work. The remainder of workers, those compensated with a monthly or annual salary, do not report such a measure and it needs to be inferred from their responses about total earnings and total hours worked. As hours reported in the SIPP are notoriously inaccurate, including much missing data, we discard salaried workers.

After eliminating some observations for various reasons ${ }^{11}$, we obtain a panel in which for each individual we record her employment status, the wage rate (if they are employed), the industry in which they work, and other characteristics (age, education, marital status, race, and whether they are residents of a metro area). The construction of a panel of this type is performed for each of the three SIPP surveys. In an Appendix we provide summary statistics of several variables for the workers in our three panels.

\subsection{The Distribution of Wage Changes}

We are interested in the dynamics of the wage change that presumably takes place in between two employment spells. That change in wages can be calculated in several ways. For example, one may calculate it using the logarithm of the ratio of the first wage earned after finding a job to the last wage earned in the last employment spell.

\footnotetext{
${ }^{10}$ At the time of the writing of this draft, results from all waves of the 2008 survey have not been yet released.

${ }^{11}$ In an Appendix we provide a detailed step-by-step analysis of how we reach our final sample of workers.
} 
Alternatively, it can be computed as the logarithm of the ratio of the average wage rate enjoyed while employed for several periods after having been unemployed, to the average wage rate enjoyed during the last employment spell. Here we report the statistics using the first measure; the second measure gives similar moments and the results are relegated to an Appendix.

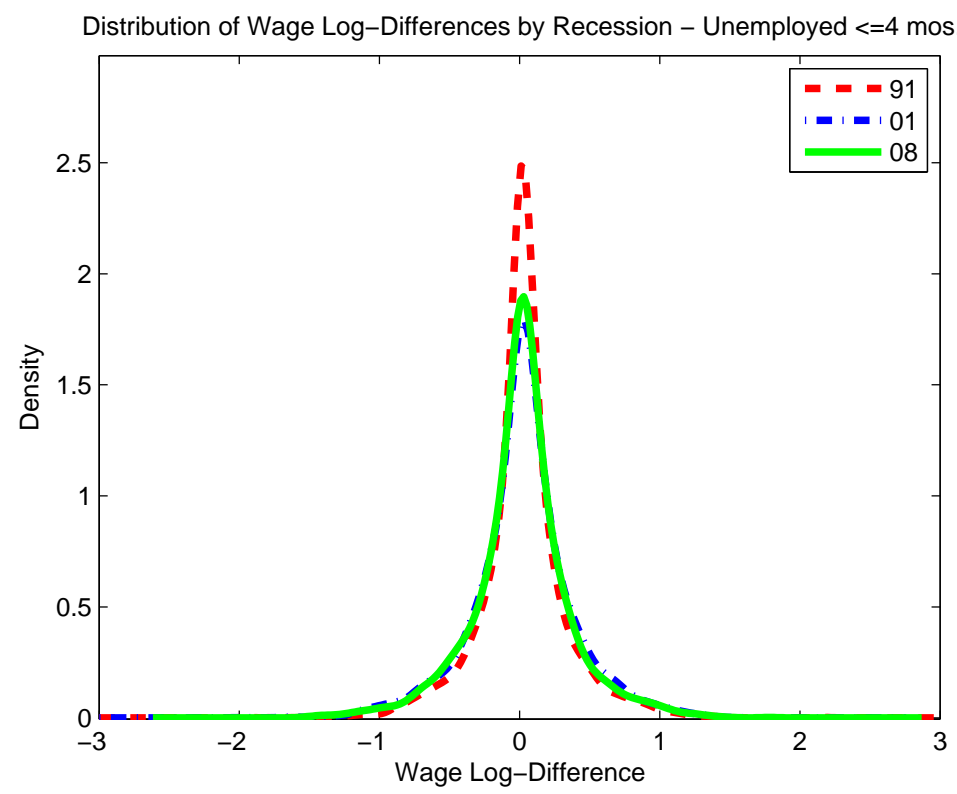

Figure 1

Measuring the change in wages using the logarithm of the ratio of the first wage after re-employment relative to the last wage earned, yields a cross-sectional distribution of wage log-differences. Figures 1 and 2 plot those cross-sectional distributions for short-term spells (those with a duration of four months or less) and long-term spells (those longer than four months). Each figure includes graphs for each of the three panels. Tables C.1 and C.2 report some moments from those distributions. ${ }^{12}$ The logdifference in wages before and after an unemployment spell is higher for individuals

\footnotetext{
${ }^{12}$ The sample sizes for all the distributions are given in the rightmost columns of Tables C.1 and C.2. These numbers seem small compared to the number of observations reported in the summary statistics table (see the Appendix). Keep in mind that table reports the number of total observations (individuals times periods) and the numbers reported in Tables C.1 and C.2 are observations of unemployment spells only.
} 
who experience long-term spells than for individuals whose spells are shorter in duration. The 2008 recession is the exception: the log-difference is -0.012 for the long-term unemployment but 0.002 for those unemployed four months or less. In the first two recessions, "patience" during the search process might tilt the growth rates upwards for the long-term unemployed (accepted wages rise in duration). It is possible that during the 2008 recessions human capital losses might lower the wage in the new job, lowering the mean growth rate. Positing and testing a theory is outside the scope of this paper but the aging of the workforce might be a factor behind the pattern: as workers age, the stock of firm- or occupation-specific human capital increases. These types of capital depreciate after a long unemployment spell becoming the dominant force in the change in wages.

The dispersion in the wage changes for the long-term unemployed is higher than for the short term unemployed. The possible exception is the 2008 recession in which the point estimate for the standard deviation is higher for the long-term, but the difference is small.

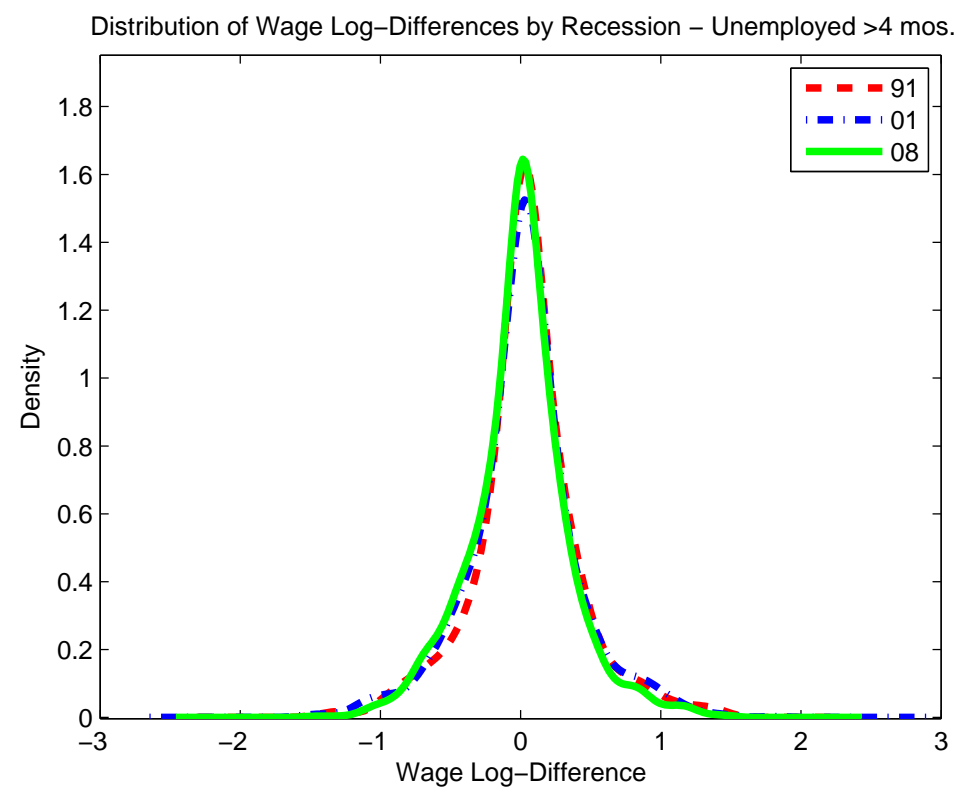

Figure 2 
About half of wage changes are negative; the median for all years and for both short-term and long-term unemployment is zero. ${ }^{13,14}$ The shapes of these distributions contrast with the conventional wisdom that nominal wages change little. Drops can be substantial for many individuals and it is not rare to record wage log-differences lower than -0.7. Extreme values appear to be more common after short-spells than long-spells.

Evidence is thus consistent with a large degree of heterogeneity among the longterm unemployed. Some of these workers are possibly individuals with a considerable buffer stock of savings that can be depleted during their job search. Yet others experience large human capital losses and eventually have to accept relatively low wage offers. In light of this heterogeneity, it is not surprising that the distribution of wage changes for the long-unemployed is relatively dispersed.

Finally, the distribution of wage changes after a short-term spell is negatively skewed. For long-term spells, skewness is positive. The 2001 recession stands out relative to the the other two, as overall skewness decreases becoming more negative for short-term spells and closer to zero for long-term spells.

\subsection{Individual Characteristics and Wage Changes}

The unconditional distributions of wage changes shown in the previous section are only the first step in understanding wage dynamics across recessions. The distribution of workers across other characteristics (age, race, education, or marital status) has

\footnotetext{
${ }^{13}$ That the median is exactly zero may reflect measurement error to some extent. The fraction of individuals who report exactly the same wage pre- and post-unemployment are $19.03 \%$ in 1991, 10.47\% in 2001, and $12.39 \%$ in 2008. Some of these cases could represent individuals who are recalled for the same position at the same firm after a temporary layoff. However, since wage rates are usually rounded to the nearest 50 cents it is not surprising that for a significant fraction of individuals, when they perform roughly the same task across jobs, wage rates do not change.

${ }^{14} \mathrm{~A}$ recent paper by Veramendi (2011) uses Danish data to compare wage rates the pre- and postunemployment. He finds that $50 \%$ of workers who experience an unemployment spell are re-employed at higher-wages. That is the fraction we find as well, both for long-term and short-term unemployed. On the other hand, studying the Spanish economy Rosolia and Saint-Paul (1998) find that, on average, wages post-unemployment are about $30 \%$ lower than before unemployment.
} 
changed over time. To measure the statistical relationship between observables and wage changes, we regress the (log) wage changes pre- and post-unemployment on some variables of interest. Specifically we fit,

$$
\log \left(w_{i, k}\right)-\log \left(w_{i, k-s-1}\right)=\gamma X_{i, k}+\sum_{t=1}^{T} \phi_{t} \chi_{i, t}+\epsilon_{i, k}
$$

The left-hand-side variable of equation (1) is the (log) wage change for an individual $i$. In other words, it is the logarithm of the variable summarized in Tables C.1 and C.2. To be even more specific, an individual experiences an unemployment spell of length $s$ which ends in period $k$. Re-employment lands that individual a job at wage $w_{i, k}$. Therefore, her last wage before the unemployment spell is $w_{i, k-s-1}$. The left-hand-side is the difference in the logarithms of those two wages. The right-hand side of the equation includes a vector $X_{i, k}$ of individual characteristics at the time of re-employment. The variables that comprise $X$ are: age, gender, marital status, education, ethnicity, whether the individual resides in a metropolitan area, the length of the unemployment spell, and whether the new employment is in a different industry (compared to the last job). ${ }^{15}$ Besides $X$, the right-hand side also shows a set of timedummies $\chi: T$ is the length of the panel, $t$ denotes calendar time, and $\chi$ takes the value $\chi_{i, t}=1$ if $t=k$ and $\chi_{i, t}=0$ otherwise. These time-dummies reflect aggregate factors that affect wage changes beyond the influence of individual characteristics. Finally, $\epsilon_{i, k}$ denotes the error term. Summarizing, the coefficients in equation (1) quantify the relationship between observable variables (both at the individual-level and an aggregate time effect) and the change in wages experienced after an unemployment spell.

Tables C.3 - C.5 report the results of fitting equation (1) to each of the three surveys $(1991,2001,2008)$. Age is a negative factor for the wage differentials before and after an unemployment spell. ${ }^{16}$ Put differently, after an unemployment spell older workers

\footnotetext{
${ }^{15}$ Individuals are assigned to one of 23 different industries. To increase the accuracy of the industryswitch coefficient we restrict ourselves to those major groups (the two-digit level).

${ }^{16}$ Although the coefficient on age ${ }^{2}$ is positive and significant, the effect on wage is several orders of magnitude smaller than the effect of age.
} 
suffer lower wages. This finding is consistent with losses of job-specific human capital increasing with tenure. The latter is positively associated with age. Given the milder nature of the 2001 recession relative to the other two, it is not surprising that wage changes associated with age were also less severe. The coefficients, while negative, are an order of magnitude smaller than those of 1991 and 2008. Another piece of evidence consistent with human capital losses is the coefficient on switching industries. It is negative across the board, and the effects are stronger for the short-term unemployed and even stronger for the 2001 and 2008 recessions than for 1991. We remain agnostic about whether this factor contributes to explain the longer recovery in employment after the recessions of 2001 and 2008. But the difference in magnitude of wage drops after an industry switch is so large across downturns, it calls for additional investigation.

Education is another variable whose effects on wages change across business cycles. In 1991, the effect of education on wage changes is U-shaped. In other words, after an unemployment spell, wages of individuals with less than a high school diploma or with a college degree drop less than those of individuals who are high-school graduates or those with some college. The pattern is evident for short- and long-term spells. In 2001 the pattern disappears and wage changes are a decreasing function of education: wage growth after a spell is high for the least-educated individuals. This finding supports the view that the 2001 recession hit hard sectors with a higher-thanaverage education level. In 2008 the relationship between wage changes and education becomes positive. Finally, married short-unemployed enjoy lower wages upon re-employment. This finding is consistent with married people being more eager to return to employment and therefore more willing to accept a lower wage. Such effects are weaker for the long- term unemployed. Surprisingly, the length of unemployment does not have a significant impact on wage beyond the distinction between short and long term.

In Table C.6 we inspect more closely the effects of switching industries on wages. We divide industries in five groups: Agriculture, Manufacturing, Construction, Low- 
Skill Services, and High-Skill Services. ${ }^{17}$ We assign workers in our sample to a group according to the industry reported at the time of the job loss. We re-define an industry switch as losing a job in one of the five industries and being re-employed in one of the other four. For each industry we fit equation (1) with the same controls as those shown in Tables C.3-C.5. Table C.6 reports the coefficient for the re-defined industry switch variable for each of the three recessions. ${ }^{18}$ Several conclusions can be drawn from the table. The first is that inter-industry wage changes are more pronounced for the 2001 and 2008 recessions than for 1991. Excepting agriculture in the past two recessions, workers in all other sectors experience large wage changes. Depending on the sector, some of these changes are positive, some are negative. Construction and manufacturing, for instance, are associated with large wage drops. In some cases the results are simply staggering: wages, on average, for workers exiting construction around the 2008 recession fell about 20\%. Even in 2001, when the construction sector was about to begin a pronounced boom, wages fell about $14 \%$ for workers moving into other industries. Exits from high-skill services to any of the other four industries are associated with mild wage drops (about 6\% in 2001 and 2008). The data also shows that transitions from low-skill services to other industries are associated with wage increases, in some cases substantial. The magnitudes of these increases have been about the same order across the past three recessions: 9.7\% for 1991, 8.4\% for 2001, and 13.1\% for 2008 .

\subsection{Nominal Wage Rigidity Across Recessions}

The analysis in this section concerns the degree of wage rigidity across business cycles. As summarized in the introduction, several theories link the lack of response of wages to aggregate conditions (the unemployment rate and inflation) to the sluggish recov-

\footnotetext{
${ }^{17}$ The Low-Skill Services group includes Personal Services, Transportation, Retail Trade, Wholesale Trade, Private Households, Entertainment/Recreation and Social Services. The High-Skill group includes Communication, Utilities, Finance, Business Services, Hospitals, Medical and Education.

${ }^{18}$ The coefficients for all other control variables in these industry-specific regressions are available upon request.
} 
ery of employment levels observed after particular downturns. The methodology we employ follows a large body of literature and the first stage of that methodology involves projecting wage changes on individual characteristics and time dummies. The estimates from this projection are the basis of the discussion in Section 2.3. Recall the regression equation is,

$$
\log \left(w_{i, k}\right)-\log \left(w_{i, k-s-1}\right)=\gamma X_{i, k}+\sum_{t=1}^{T} \phi_{t} \chi_{i, t}+\epsilon_{i, k} .
$$

The coefficients $\left\{\phi_{t}\right\}_{t=1}^{T}$ can be interpreted as the change in aggregate wages over time controlling for heterogeneity across workers. The second stage of the methodology involves regressing those coefficients on the changes in the aggregate unemployment rate: ${ }^{19}$

$$
\phi_{t}=\alpha+\beta \Delta U_{t}+v_{t}
$$

In this equation $\Delta U_{t}$ denotes the monthly change of unemployment rate and $v_{t}$ is an error term. The coefficient $\beta$ is our measure of the degree of cyclicality of nominal wages (or more precisely the cyclicality of nominal wage changes). Thus, comparing $\beta$ across recessions yields a comparison of the degree of wage rigidity across recessions. When $\beta<0$ wages are procyclical; the closer $\beta$ is to zero, the weaker the reaction of wages to aggregate conditions in the labor market. Following this strategy, we run the two-step regression for each of the three surveys described earlier. Since the short-term unemployed and long-term unemployed differ along several dimensions, we perform the same two-step analysis separately for short-term and long-term spells, as well as for all workers simultaneously.

Table C.7 reports the estimated $\beta$ 's for the three recessions. The estimates show that of the three downturns 2008 has the highest degree of procyclicality in wages. The coefficient is negative and significant for all workers and for short-term spells. The

\footnotetext{
${ }^{19}$ Below we introduce additional right-hand-side variables, e.g. the inflation rate.
} 
point estimates for the 2001 recession show the opposite picture: coefficients are positive (although there is uncertainty around those point estimates) for all workers except for the long-term unemployed. Finally, the relationship between unemployment and wages in 1991 between the other two recessions. The relationship is weak for the shortterm unemployed, but the cyclicality for the long-term unemployed is similar to that of 2008. The evidence we present weakens the hypothesis of works that assign a large role to wage rigidity as an explanation for the unemployment dynamics during the 2008 recession and its subsequent recovery. It is a more probable explanation for the jobless recovery and weak employment growth in the recession and recovery around 2001.

\subsubsection{Robustness}

We assess the robustness of the results shown to alternative definitions of right-hand or left-hand side variables in the second-step regression. These alternatives concern adjusting for seasonality, the relationship between accumulated past changes in the unemployment rate and wage changes, and the behavior of inflation.

Because there is no adjustment for seasonality in wages in equation (1), the estimated time coefficient $\phi$ captures some seasonal effects. To be consistent, in the benchmark estimation we use the non-seasonally adjusted unemployment rate to estimate equation (2). An alternative is to seasonally-adjust wage changes in the first-stage regression by including quarterly dummy variables and use the seasonally-adjusted unemployment rate as the independent variable in the second-step regression. The results of this exercise are reported in Table C.8. In contrast to the weak countercyclicality in the benchmark case, wage changes during the 2001 recession are more countercyclical. During the 2008 recession the results for the change in wages for the long-term unemployed are stronger than for the short term unemployed. Despite these differences, the main message remains: during the 1991 and 2008 downturns wage changes are more pro-cyclical than in 2001. 
In the benchmark model, an increase in the unemployment rate affects wage changes immediately. In principle, past labor market condition could accumulate over time and have an impact current wages upon re-employment. To explore this hypothesis we modify equation (2) with the accumulated quarterly change in the unemployment rate as independent variable. This new specification increases the uncertainty associated with several estimates, particulary for the 2001 recession. Wages in 1991 and 2008 still show stronger countercyclicality than in 2001.

We finally ask whether the behavior of inflation is responsible for the apparent heterogeneity in nominal wage dynamics across business cycles. We measure inflation using the rate of change in the Consumer Price Index (CPI) which we add as a control in the second-step regression (equation 2). Sample uncertainty is still high but the point estimates are positive for the 2001 recession, mostly negative for 1991, and certainly negative for 2008 .

\section{Concluding Remarks}

This paper provides an empirical investigation of the behavior of individual wages for those workers who experience an unemployment spell. Employing high-frequency data on wages and unemployment, it compares the determinants of wage changes pre- and post-unemployment across different business cycles. The facts about wages and unemployment spells the paper uncovers are far from being homogeneous across different recessions. We have examined wages and unemployment spells across three dimensions. The first is exploring the unconditional distributions of wage changes preand post-unemployment; this analysis is undertaken by unemployment spell and by recession. The Great Recession stands out among the three downturns studied for its implications on wage changes for the long-term unemployed. While the 1991 and 2001 recessions showed on average larger wage gains for the long-term unemployed than for those unemployed short-term, this pattern was reversed during the 2008 recession. 
Workers' characteristics such as the years of schooling or the sector from which they lose their job affect the wage change after an unemployment spell differently, depending on the recession the worker loses her job. Finally, the paper also explores whether the degree of wage rigidity varies across recessions. Despite some authors' conjecture that the slow recovery in employment observed after the Great Recession was caused by wages being more rigid than in previous recessions, we find evidence to the contrary. Wages appear to have been more rigid in both the 1991 and 2001 recession than during the 2008 recession and recovery. 


\section{References}

[1] Barattieri, A., Basu, S. and Gottschalk, P.: (2010), "Some Evidence on the Importance of Sticky Wages," NBER Working Paper.

[2] Barlevy, G.: (2001), “Why are the Wages of Job Changers So Procyclical?," Journal of Labor Economics, 19, pp. 837-878.

[3] Bils, M. J.: (1985), “Real Wages Over the Business Cycle: Evidence from Panel Data," Journal of Political Economy, 93, pp. 666-689.

[4] Devereaux, P. J.: (2001), "The Cyclicality of Real Wages Within EmployerEmployee Matches," Industrial and Labor Relations Review, 54, pp. 835-850.

[5] Haefke C., Sonntag, M. and Van Rens, T.: (2008), "Wage Rigidity and Job Creation," IZA Working Paper 3714.

[6] Heckman, J.J. and Borjas, G.: (1980), “Does Unemployment Cause Future Unemployment? Definitions, Questions and Answers from a Continuous Time Model of Heterogeneity and State Dependence," Economica, Vol. 47, pp. 247-83.

[7] Jacobson, L.S, LaLonde, R.J., and Sullivan, D.G.: "Earnings Losses of Displaced Workers," American Economic Review, Vol. 83(4), pp. 685-709.

[8] Pissarides, C.: 1985, "Short-Run Equilibrium Dynamics of Unemployment, Vacancies, and Real Wages," American Economic Review 75(4), pp. 676-690.

[9] Pissarides, C.: 2009, “The Unemployment Volatility Puzzle: Is Wage Stickiness the Answer?," Econometrica, vol. 77(5), pp. 1339-1369.

[10] Portugal, P.: (1989), “Job Displacement, Relative Wage Changes, and Duration of Unemployment," Journal of Labor Economics, Vol. 7(3), pp. 281-302. 
[11] Rendon, S.: (2006), “Job Search and Asset Accumulation Under Borrowing Constraints,"International Economic Review, Vol. 47(1), pp. 233-263.

[12] Rosolia, A. and Saint-Paul, G.: (1998), “ The effects of unemployment spells on subsequent wages in Spain", unpublished manuscript.

[13] Shimer, R.: (2004), "The Consequences of Rigid Wages in Search Models," Journal of the European Association, 2, pp. 469-479.

[14] Shimer, R.: (2011), “Wage Rigidities and Jobless Recoveries," manuscript, University of Chicago.

[15] Shin, D.: (1994), “Cyclicality of Real Wages among Young Men,"Economics Letters, Vol. 46(2), pp. 137-42.

[16] Solon, G., Barsky, R. and Parker, J.A.: (1994), “Measuring the Cyclicality of Real Wages: How Important Is Composition Bias?", The Quarterly Journal of Economics, Vol. 109(1), pp. 1-25.

[17] Veramendi, G.F.: (2011), “Unemployment Dynamics and Wage Dispersion in a Model with Search and Human Capital Accumulation", manuscript, Aarhus University.

[18] Vishwanath, T.: (1989), “Job Search, Stigma Effect, and Escape Rate from Unemployment", Journal of Labor Economics, Vol. 7, No. 4, pp. 487-502. 


\section{A Sample Selection and Data Summary}

We perform five steps to clean-up the original sample and reach our final sample. These five steps are:

- Step 1 : Drop individuals younger than 16 years old.

- Step 2 : Keep only those individuals who are paid by the hour.

- Step 3 : Drop observations for individuals not in the labor force but who report wages.

- Step 4 : Drop observations for employed individuals who do not report wages.

- Step 5 : Eliminate the top and bottom $1 \%$ of the earnings distribution.

Table A.1 reports the number of observations lost in each of the 5 steps for all three panels.

Table A.1: Sample Selection - Steps and Lost Observations

\begin{tabular}{cccc}
\hline & 1991 & 2001 & 2008 \\
\hline Step 1 & 281,063 & 618,285 & 656,432 \\
Step 2 & 710,791 & $1,565,708$ & $2,790,583$ \\
Step 3 & 479 & 15,726 & 19,990 \\
Step 4 & 951 & 21,611 & 17,967 \\
Step 5 & 6,738 & 27,292 & 32,080 \\
\hline
\end{tabular}

Table A.2 reports some summary statistics for each of the three downturns and variables used to control for individual level characteristics in the first-step regression. 
Table A.2: Summary Statistics

\begin{tabular}{lccccccccc}
\hline & \multicolumn{3}{c}{1991 Panel, $N=620,615$} & \multicolumn{5}{c}{ 2001 Panel, $N=1,446,503$} \\
\cline { 2 - 9 } Age & Mean & Std. Dev. & Min. & Max. & Mean & Std. Dev. & Min. & Max. \\
\cline { 2 - 9 } Female & 0.538 & 19.781 & 16 & 85 & 44.382 & 19.777 & 16 & 87 \\
$<$ HS & 0.304 & 0.495 & 0 & 1 & 0.567 & 0.495 & 0 & 1 \\
HS & 0.354 & 0.460 & 0 & 1 & 0.247 & 0.432 & 0 & 1 \\
SC & 0.235 & 0.424 & 0 & 1 & 0.290 & 0.454 & 0 & 1 \\
$\mathrm{C}$ & 0.106 & 0.308 & 0 & 1 & 0.095 & 0.295 & 0 & 1 \\
White & 0.767 & 0.423 & 0 & 1 & 0.690 & 0.462 & 0 & 1 \\
Married & 0.524 & 0.499 & 0 & 1 & 0.477 & 0.500 & 0 & 1 \\
Metro & 0.715 & 0.452 & 0 & 1 & 0.747 & 0.434 & 0 & 1 \\
\hline
\end{tabular}

\begin{tabular}{lcccc} 
& \multicolumn{4}{l}{ 2008 Panel, $N=1,684,251$} \\
\cline { 2 - 4 } Age & Mean & Std. Dev. & Min. & Max. \\
\cline { 2 - 5 } Female & 46.125 & 20.246 & 16 & 87 \\
$<$ HS & 0.563 & 0.500 & 0 & 1 \\
HS & 0.313 & 0.387 & 0 & 1 \\
SC & 0.346 & 0.476 & 0 & 1 \\
C & 0.112 & 0.316 & 0 & 1 \\
White & 0.787 & 0.409 & 0 & 1 \\
Married & 0.460 & 0.498 & 0 & 1 \\
Metro & 0.751 & 0.432 & 0 & 1 \\
\hline
\end{tabular}

Notes: Summary statistics for the sample of workers in the 1991,2001, and 2008 panels. The education categories are as follows: $<H S$ is less than a high school diploma; HS is a high school graduate; $S C$ is college enrollment without degree; and $C$ is college degree. 


\section{B Additional Results}

\section{B.1 An Alternative Measure of the Change in Wages}

This section provides an analysis analogous to that of Section 2.2. In that section we measure the change in wages as the difference in the logarithm of the initial wage after an unemployment spell and the last wage before a job separation. Here we show statistics when the change is measured by the difference in the logarithm of the average wage across subsequent employment spells. Figures 3 and 4 show the unconditional distributions of the change in wages and Tables B.1 and B.2 the same summary statistics as those shown on Tables C.1 and C.2. Most of the conclusions drawn in Section 2.2 carry over to the alternative measure of the change in wages presented here. In particular, the dispersion of the change in wages is higher for long-term spells, and the 2008 recession displays a low mean for wage growth after long-term spells. The statistic that looks rather different is skewness. In Section 2.2 the distribution of the change in wages after short-term spells was characterized by negative skewness; skewness was positive for long-term spells. When we take the difference between the two average wages observed across two different employment spells, there is no clear relationship between the length of the spell and the degree of skewness of the distribution of wage changes. It is still the case, however, that the 2001 distribution is much more negatively skewed than the distributions during the 1991 or 2008 recessions.

Table B.1: Distribution of (Average) Log-Wage Differences - Short-Term Unemployed

\begin{tabular}{lccccccc}
\hline & Min. & Mean & Median & Max. & Std. Dev. & Skewness & $\mathrm{N}$ \\
\cline { 2 - 7 } 1991 & -1.958 & 0.036 & 0.019 & 2.252 & 0.293 & 0.024 & 3,134 \\
2001 & -1.657 & 0.035 & 0.0377 & 1.572 & 0.332 & -0.242 & 3,222 \\
2008 & -1.520 & 0.012 & 0.016 & 1.772 & 0.336 & -0.085 & 2,438 \\
\hline
\end{tabular}




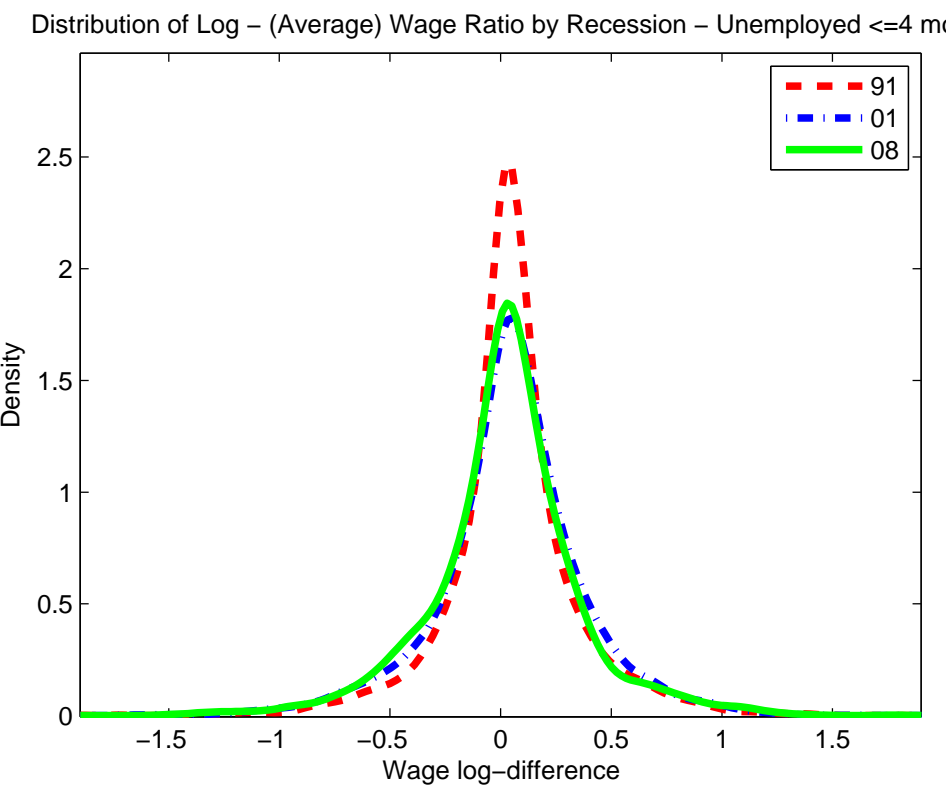

Figure 3

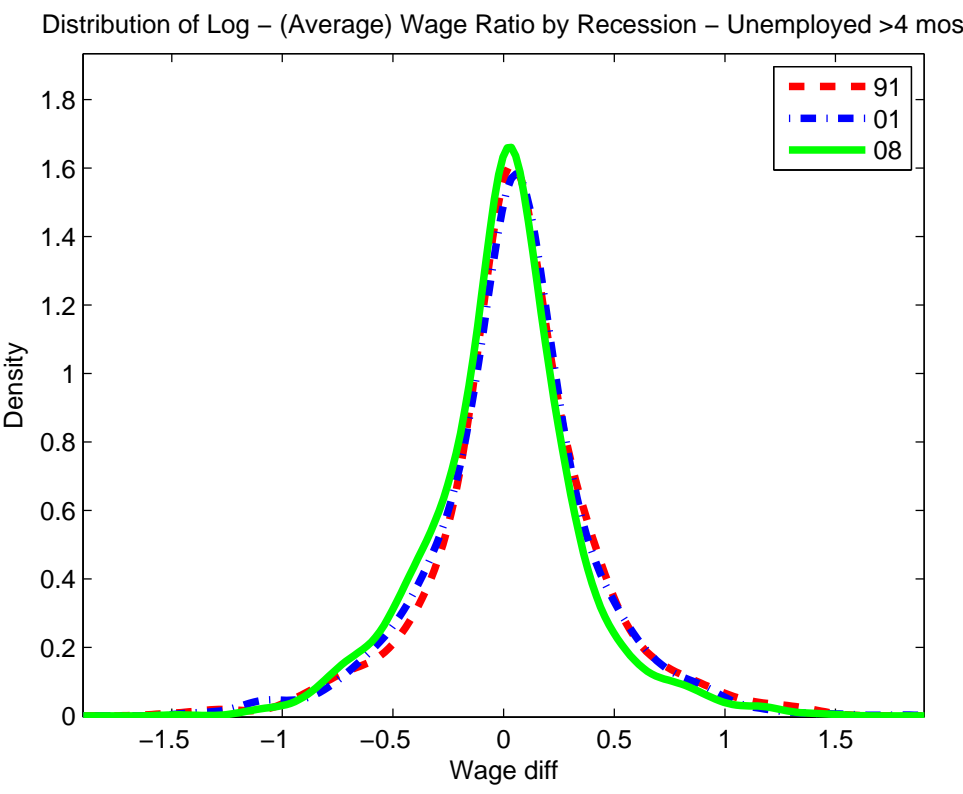

Figure 4 
Table B.2: Distribution of (Average) Log-Wage Differences - Long-Term Unemployed

\begin{tabular}{cccccccc}
\hline & Min. & Mean & Median & Max. & Std. Dev. & Skewness & $\mathrm{N}$ \\
\cline { 2 - 8 } 1991 & -1.495 & 0.046 & 0.030 & 1.378 & 0.364 & -0.057 & 603 \\
2001 & -1.446 & 0.028 & 0.037 & 1.792 & 0.362 & -0.102 & 1,707 \\
2008 & -1.481 & -0.007 & 0.000 & 1.455 & 0.339 & 0.112 & 1,434 \\
\hline
\end{tabular}

\section{B.2 Wage Rigidity During Expansions: 1996 and 2004}

This sections performs the same analysis regarding wage rigidity but instead of focusing on recessions, it focuses on the expansionary periods 1996-2000 and 2006-2007. To arrive at our final sample we perform the same steps as when we analyze recessions, and we fit the same two regression equations, (1) and (2). In reporting the results we maintain the same format as for all other regressions shown: we only report the coefficient on the (difference of) the unemployment rate. As is clear from the Tables, those coefficients have small magnitudes in absolute value, irrespective of whether one looks at all workers, those suffering short-term spells, or those unemployed for longer. Wages after unemployment spells seem to react little to changes in aggregate labor market conditions. 
Table B.3: Benchmark: 1996 and 2004 Expansions

\begin{tabular}{cccc}
\hline & 1996 All & 1996 Short & 1996 Long \\
\hline$\Delta U_{t}$ & 0.019 & 0.017 & 0.009 \\
& $(1.12)$ & $(0.90)$ & $(0.54)$ \\
Intercept & -0.008 & -0.077 & 0.148 \\
& $(-1.27)$ & $(-10.85)$ & $(22.33)$ \\
\hline & 2004 All & 2004 Short & 2004 Long \\
\hline \multirow{4}{*}{$\Delta U_{t}$} & -0.004 & -0.003 & 0.002 \\
& $(1.12)$ & $(-0.11)$ & $(0.05)$ \\
Intercept & 0.110 & 0.217 & 0.02 \\
& $(15.24)$ & $(27.81)$ & $(2.19)$ \\
\hline
\end{tabular}

Table B.4: Accumulated Effects: 1996 and 2004 Expansions

\begin{tabular}{cccc}
\hline & 1996 All & 1996 Short & 1996 Long \\
$\Delta U_{t}$ & 0.015 & 0.014 & 0.004 \\
& $(0.88)$ & $(0.73)$ & $(0.25)$ \\
\hline & & & \\
\hline \multirow{4}{*}{$\Delta U_{t}$} & 2004 All & 2004 Short & 2004 Long \\
& -0.017 & -0.010 & -0.019 \\
& $(-0.64)$ & $(-0.34)$ & $(-0.54)$ \\
\hline
\end{tabular}

Table B.5: Inflation Adjustment: 1996 and 2004 Expansions

\begin{tabular}{cccc}
\hline & 1996 All & 1996 Short & 1996 Long \\
\hline$\Delta U_{t}$ & -0.003 & 0.017 & 0.009 \\
& $(-0.12)$ & $(0.88)$ & $(0.53)$ \\
Intercept & 0.108 & -0.075 & 0.149 \\
& $(12.73)$ & $(-6.96)$ & $(15.38)$ \\
\hline \hline \multirow{4}{*}{$\Delta U_{t}$} & 2004 All & 2004 Short & 2004 Long \\
& -0.003 & -0.0002 & -0.0007 \\
Intercept & $(-0.12)$ & $(0.01)$ & $(0.02)$ \\
& 0.108 & 0.212 & 0.023 \\
& $(12.73)$ & $(23.37)$ & $(2.10)$ \\
\hline
\end{tabular}




\section{Tables}

Table C.1: Distribution of Wage Log-Differences - Short-Term Unemployed

\begin{tabular}{lccccccc}
\hline & Min. & Mean & Median & Max. & Std. Dev. & Skewness & $\mathrm{N}$ \\
\cline { 2 - 8 } 1991 & -1.958 & 0.008 & 0.000 & 2.169 & 0.310 & -0.025 & 3,134 \\
2001 & -1.984 & 0.007 & 0.000 & 1.572 & 0.361 & -0.175 & 3,222 \\
2008 & -1.520 & 0.002 & 0.000 & 1.772 & 0.350 & -0.069 & 2,438 \\
\hline
\end{tabular}

Table C.2: Distribution of Wage Log-Differences - Long-Term Unemployed

\begin{tabular}{lccccccc}
\hline & Min. & Mean & Median & Max. & Std. Dev. & Skewness & $\mathrm{N}$ \\
\cline { 2 - 8 } 1991 & -1.386 & 0.034 & 0.000 & 1.386 & 0.372 & 0.087 & 603 \\
2001 & -1.539 & 0.010 & 0.000 & 1.792 & 0.387 & 0.011 & 1,707 \\
2008 & -1.481 & -0.012 & 0.000 & 1.453 & 0.351 & 0.095 & 1,434 \\
\hline
\end{tabular}


Table C.3: Summary of the First Regression

\begin{tabular}{rlll}
\hline & 1991 All & 1991 Short & 1991 Long \\
\hline Age & $-0.013^{* * *}$ & $-0.010^{* * *}$ & $-0.026^{* * *}$ \\
& $(-5.48)$ & $(-4.29)$ & $(-3.52)$ \\
Age $^{2}$ & $0.00013^{* * *}$ & $0.00010^{* * *}$ & $0.00029^{* * *}$ \\
& $(4.68)$ & $(3.47)$ & $(3.19)$ \\
Female & $0.053^{* * *}$ & $0.049^{* * *}$ & $0.077^{* *}$ \\
& $(4.54)$ & $(-3.97)$ & $(2.22)$ \\
HS & $-0.033^{* *}$ & $-0.031^{* *}$ & -0.012 \\
& $(-2.32)$ & $(-2.09)$ & $(-0.29)$ \\
SC & -0.013 & -0.016 & 0.025 \\
& $(-1.00)$ & $(-1.12)$ & $(0.61)$ \\
$C$ & 0.028 & 0.018 & 0.091 \\
& $(1.26)$ & $(0.76)$ & $(0.1 .31)$ \\
Married & $-0.039^{* * *}$ & $-0.039^{* * *}$ & -0.051 \\
& $(-2.95)$ & $(-2.84)$ & $(-1.21)$ \\
Black & 0.002 & 0.014 & 0.004 \\
& $(-0.07)$ & $(-0.43)$ & $(-0.04)$ \\
White & 0.008 & 0.002 & 0.004 \\
& $(0.32)$ & $(0.06)$ & $(0.06)$ \\
Hispanic & 0.014 & 0.020 & -0.046 \\
& $(0.46)$ & $(0.62)$ & $(-0.51)$ \\
Metro & -0.008 & -0.004 & 0.028 \\
& $(-0.12)$ & $(-0.34)$ & $(-0.79)$ \\
U-Spell & 0.003 & 0.005 & -0.003 \\
& $(1.04)$ & $(0.98)$ & $(-0.42)$ \\
& -0.006 & -0.009 & -0.008 \\
& $(-0.55)$ & $(-0.78)$ & $(-0.24)$ \\
\hline Ind-Switch & &
\end{tabular}


Table C.4: Summary of the First Regression

\begin{tabular}{|c|c|c|c|}
\hline & 2001 All & 2001 Short & 2001 Long \\
\hline Age & $\begin{array}{l}-0.006^{* * *} \\
(-2.94)\end{array}$ & $\begin{array}{l}-0.006^{* *} \\
(-2.29)\end{array}$ & $\begin{array}{l}-0.006 \\
(-1.51)\end{array}$ \\
\hline Age $^{2}$ & $\begin{array}{l}0.00004^{*} \\
(-1.70)\end{array}$ & $\begin{array}{l}0.00004 \\
(1.2)\end{array}$ & $\begin{array}{l}0.00005 \\
(0.98)\end{array}$ \\
\hline Female & $\begin{array}{l}0.014 \\
(1.19)\end{array}$ & $\begin{array}{l}0.017 \\
(1.19)\end{array}$ & $\begin{array}{l}0.011 \\
(0.52)\end{array}$ \\
\hline$H S$ & $\begin{array}{l}-0.006 \\
(-0.47)\end{array}$ & $\begin{array}{l}-0.009 \\
(-0.53)\end{array}$ & $\begin{array}{l}-0.004 \\
(-0.14)\end{array}$ \\
\hline$S C$ & $\begin{array}{l}-0.017 \\
(-1.14)\end{array}$ & $\begin{array}{l}-0.017 \\
(-0.94)\end{array}$ & $\begin{array}{l}-0.036 \\
(-1.33)\end{array}$ \\
\hline C & $\begin{array}{l}-0.029 \\
(-1.29)\end{array}$ & $\begin{array}{l}-0.060^{* *} \\
(-2.16)\end{array}$ & $\begin{array}{l}0.007 \\
(0.17)\end{array}$ \\
\hline Married & $\begin{array}{l}-0.021 \\
(-1.58)\end{array}$ & $\begin{array}{l}-0.016 \\
(-1.08)\end{array}$ & $\begin{array}{l}-0.027 \\
(-1.02)\end{array}$ \\
\hline Black & $\begin{array}{l}-0.0004 \\
(-0.02)\end{array}$ & $\begin{array}{l}0.015 \\
(-0.44)\end{array}$ & $\begin{array}{l}0.014 \\
(0.25)\end{array}$ \\
\hline White & $\begin{array}{l}-0.020 \\
(-0.75)\end{array}$ & $\begin{array}{l}-0.058^{*} \\
(-1.84)\end{array}$ & $\begin{array}{l}0.040 \\
(0.77)\end{array}$ \\
\hline Hispanic & $\begin{array}{l}0.019 \\
(0.66)\end{array}$ & $\begin{array}{l}-0.001 \\
(-0.08)\end{array}$ & $\begin{array}{l}0.052 \\
(0.92)\end{array}$ \\
\hline Metro & $\begin{array}{l}0.002 \\
(0.16)\end{array}$ & $\begin{array}{l}-0.013 \\
(-0.85)\end{array}$ & $\begin{array}{l}0.016 \\
(0.69)\end{array}$ \\
\hline U-Spell & $\begin{array}{l}0.002^{*} \\
(1.88)\end{array}$ & $\begin{array}{l}-0.008 \\
(-1.06)\end{array}$ & $\begin{array}{l}-0.002 \\
(-0.55)\end{array}$ \\
\hline Ind-Switch & $\begin{array}{l}-0.042^{* * *} \\
(-3.78)\end{array}$ & $\begin{array}{l}-0.049^{* * *} \\
(-3.69)\end{array}$ & $\begin{array}{l}-0.034 \\
(-1.57)\end{array}$ \\
\hline
\end{tabular}


Table C.5: Summary of the First Regression

\begin{tabular}{|c|c|c|c|}
\hline & 2008 All & 2008 Short & 2008 Long \\
\hline Age & $\begin{array}{l}-0.016^{* * *} \\
(-5.27)\end{array}$ & $\begin{array}{l}-0.013^{* * *} \\
(-3.29)\end{array}$ & $\begin{array}{l}-0.023^{* * *} \\
(-4.51)\end{array}$ \\
\hline $\mathrm{Age}^{2}$ & $\begin{array}{l}0.00017^{* * *} \\
(4.50)\end{array}$ & $\begin{array}{l}0.00012^{* * *} \\
(2.63)\end{array}$ & $\begin{array}{l}0.00026^{* * *} \\
(4.06)\end{array}$ \\
\hline Female & $\begin{array}{l}0.021 \\
(1.35)\end{array}$ & $\begin{array}{l}0.018 \\
(0.98)\end{array}$ & $\begin{array}{l}0.022 \\
(0.83)\end{array}$ \\
\hline$H S$ & $\begin{array}{l}0.011 \\
(0.53)\end{array}$ & $\begin{array}{l}0.009 \\
(0.34)\end{array}$ & $\begin{array}{l}0.034 \\
(0.94)\end{array}$ \\
\hline$S C$ & $\begin{array}{l}0.036^{*} \\
(1.75)\end{array}$ & $\begin{array}{l}0.036 \\
(1.40)\end{array}$ & $\begin{array}{l}0.043 \\
(1.15)\end{array}$ \\
\hline C & $\begin{array}{l}0.078^{* * *} \\
(2.66)\end{array}$ & $\begin{array}{l}0.053 \\
(1.46)\end{array}$ & $\begin{array}{l}0.171^{* * *} \\
(3.12)\end{array}$ \\
\hline Married & $\begin{array}{l}-0.035^{* *} \\
(-1.95)\end{array}$ & $\begin{array}{l}-0.037^{*} \\
(-1.68)\end{array}$ & $\begin{array}{l}-0.034 \\
(-1.08)\end{array}$ \\
\hline Black & $\begin{array}{l}0.001 \\
(0.04)\end{array}$ & $\begin{array}{l}-0.028 \\
(-0.72)\end{array}$ & $\begin{array}{l}0.067 \\
(1.31)\end{array}$ \\
\hline White & $\begin{array}{l}-0.012 \\
(-0.47)\end{array}$ & $\begin{array}{l}-0.048 \\
(-0.49)\end{array}$ & $\begin{array}{l}0.063 \\
(1.46)\end{array}$ \\
\hline Hispanic & $\begin{array}{l}0.016 \\
(0.80)\end{array}$ & $\begin{array}{l}0.005 \\
(0.20)\end{array}$ & $\begin{array}{l}0.043 \\
(1.15)\end{array}$ \\
\hline Metro & $\begin{array}{l}-0.006 \\
(-0.38)\end{array}$ & $\begin{array}{l}-0.011 \\
(-0.56)\end{array}$ & $\begin{array}{l}0.020 \\
(0.67)\end{array}$ \\
\hline U-Spell & $\begin{array}{l}0.002 \\
(0.78)\end{array}$ & $\begin{array}{l}-0.015 \\
(-1.35)\end{array}$ & $\begin{array}{l}-0.003 \\
(-0.51)\end{array}$ \\
\hline Ind-Switch & $\begin{array}{l}-0.027^{*} \\
(-1.87)\end{array}$ & $\begin{array}{l}-0.049^{* * *} \\
(-2.73)\end{array}$ & $\begin{array}{l}0.011 \\
(0.41)\end{array}$ \\
\hline
\end{tabular}


Table C.6: Industry Specific Regression - Coefficient on Industry Transition

\begin{tabular}{rccc}
\hline & 1991 & 2001 & 2008 \\
\hline Agriculture & -0.019 & -0.011 & -0.022 \\
& $(-0.30)$ & $(-0.09)$ & $(-0.39)$ \\
Manufact. & -0.035 & -0.080 & $-0.099^{* *}$ \\
& $(-0.94)$ & $(-1.37)$ & $(-2.21)$ \\
Construct. & -0.017 & $-0.137^{* *}$ & $-0.188^{* * *}$ \\
& $(-0.34)$ & $(-2.00)$ & $(-3.7)$ \\
Low-Skill Serv. & $0.097^{* * *}$ & $0.084^{* * *}$ & $0.131^{* * *}$ \\
& $(5.93)$ & $(5.17)$ & $(6.22)$ \\
High-Skill Serv. & -0.003 & $-0.06^{* * *}$ & -0.056 \\
& $(-0.12)$ & $(-3.18)$ & $(-1.84)$ \\
\hline
\end{tabular}

Table C.7: Benchmark: 1991, 2001, and 2008 Recessions

\begin{tabular}{cccc}
\hline & 1991 All & 1991 Short & 1991 Long \\
\hline$\Delta U_{t}$ & $\begin{array}{c}0.0005 \\
(0.08)\end{array}$ & $\begin{array}{c}0.009 \\
(0.46)\end{array}$ & $\begin{array}{c}-0.113^{*} \\
(-1.71)\end{array}$ \\
Intercept & $\begin{array}{c}0.067^{* * *} \\
(8.00)\end{array}$ & $\begin{array}{c}0.075^{* * *} \\
(8.56)\end{array}$ & $\begin{array}{c}0.059^{* *} \\
(2.13)\end{array}$ \\
\hline & & & \\
\hline & $2001 \mathrm{All}$ & 2001 Short & 2001 Long \\
\hline$\Delta U_{t}$ & 0.021 & 0.027 & -0.004 \\
& $(1.04)$ & $(1.18)$ & $(-0.12)$ \\
Intercept & $0.073^{* * *}$ & $0.227^{* * *}$ & $-0.052^{* * *}$ \\
& $(10.46)$ & $(28.67)$ & $(-4.82)$ \\
\hline \hline & $2008 \mathrm{All}$ & 2008 Short & 2008 Long \\
\hline \multirow{2}{*}{$\Delta U_{t}$} & $-0.046^{* *}$ & $-0.050^{*}$ & -0.022 \\
& $(-2.27)$ & $(-2.39)$ & $(-0.59)$ \\
Intercept & $0.111^{* * *}$ & 0.016 & 0.163 \\
& $(12.04)$ & $(-1.63)$ & $(11.65)$ \\
\hline
\end{tabular}


Table C.8: Alternative Seasonal Adjustment: 1991, 2001, and 2008 Recessions

\begin{tabular}{|c|c|c|c|}
\hline & 1991 All & 1991 Short & 1991 Long \\
\hline$\Delta U_{t}$ & $\begin{array}{l}-0.058 \\
(-0.75)\end{array}$ & $\begin{array}{l}-0.088 \\
(-1.11)\end{array}$ & $\begin{array}{c}0.214 \\
(0.8)\end{array}$ \\
\hline \multirow[t]{2}{*}{ Intercept } & $\begin{array}{c}0.303^{* * *} \\
(2.9)\end{array}$ & $\begin{array}{c}0.025^{* *} \\
(2.3)\end{array}$ & $\begin{array}{c}0.083^{* *} \\
(2.32)\end{array}$ \\
\hline & 2001 All & 2001 Short & 2001 Long \\
\hline$\Delta U_{t}$ & $\begin{array}{c}0.227^{* *} \\
(3.05)\end{array}$ & $\begin{array}{c}0.316^{*} \\
(1.98)\end{array}$ & $\begin{array}{l}0.046 \\
(0.37)\end{array}$ \\
\hline \multirow[t]{2}{*}{ Intercept } & $\begin{array}{l}0.009 \\
(0.86)\end{array}$ & $\begin{array}{c}0.054^{* *} \\
(2.36)\end{array}$ & $\begin{array}{c}0.007 \\
(0.4)\end{array}$ \\
\hline & 2008 All & 2008 Short & 2008 Long \\
\hline$\Delta U_{t}$ & $\begin{array}{l}-0.047 \\
(-0.72)\end{array}$ & $\begin{array}{l}-0.025 \\
(-0.28)\end{array}$ & $\begin{array}{c}-0.22^{* *} \\
(-2.73)\end{array}$ \\
\hline Intercept & $\begin{array}{l}0.023 \\
(1.55)\end{array}$ & $\begin{array}{l}0.002 \\
(0.12)\end{array}$ & $\begin{array}{l}0.003 \\
(0.17)\end{array}$ \\
\hline
\end{tabular}


Table C.9: Accumulated Effects: 1991, 2001, and 2008 Recessions

\begin{tabular}{|c|c|c|c|}
\hline & 1991 All & 1991 Short & 1991 Long \\
\hline$\Delta U_{t}$ & $\begin{array}{l}-0.008 \\
(-1.22)\end{array}$ & $\begin{array}{l}-0.008 \\
(-1.04)\end{array}$ & $\begin{array}{c}-0.016 \\
(-0.4)\end{array}$ \\
\hline \multirow[t]{2}{*}{ Intercept } & $\begin{array}{c}0.061^{* * *} \\
(11.61)\end{array}$ & $\begin{array}{c}0.070^{* * *} \\
(11.46)\end{array}$ & $\begin{array}{c}0.058^{*} \\
(1.99)\end{array}$ \\
\hline & 2001 All & 2001 Short & 2001 Long \\
\hline$\Delta U_{t}$ & $\begin{array}{l}0.007 \\
(0.56)\end{array}$ & $\begin{array}{l}0.006 \\
(0.47)\end{array}$ & $\begin{array}{l}0.001 \\
(0.06)\end{array}$ \\
\hline \multirow[t]{2}{*}{ Intercept } & $\begin{array}{c}0.073^{* * *} \\
(10.15)\end{array}$ & $\begin{array}{c}0.228^{* * *} \\
(27.65)\end{array}$ & $\begin{array}{c}-0.052^{* * *} \\
(-4.79)\end{array}$ \\
\hline & 2008 All & 2008 Short & 2008 Long \\
\hline$\Delta U_{t}$ & $\begin{array}{c}-0.026^{* *} \\
(-2.51)\end{array}$ & $\begin{array}{c}-0.025^{* *} \\
(-2.25)\end{array}$ & $\begin{array}{l}-0.019 \\
(-0.94)\end{array}$ \\
\hline Intercept & $\begin{array}{c}0.043^{* * *} \\
(3.73)\end{array}$ & $\begin{array}{c}0.087^{* * *} \\
(6.85)\end{array}$ & $\begin{array}{l}-0.010 \\
(-0.72)\end{array}$ \\
\hline
\end{tabular}


Table C.10: Inflation Adjustment: 1991, 2001, and 2008 Recessions

\begin{tabular}{cccc}
\hline & 1991 All & 1991 Short & 1991 Long \\
\hline$\Delta U_{t}$ & -0.007 & -0.007 & 0.007 \\
& $(-1.02)$ & $(-0.92)$ & $(0.18)$ \\
$\Delta \log (C P I)$ & 3.607 & 2.037 & $2.225^{*}$ \\
& $(1.35)$ & $(0.64)$ & $(1.78)$ \\
Intercept & 0.034 & $0.055^{* *}$ & -0.137 \\
& $(1.67)$ & $(2.25)$ & $(-1.21)$ \\
\hline \hline & 2001 All & 2001 Short & 2001 Long \\
\hline \multirow{4}{*}{$\Delta U_{t}$} & 0.011 & 0.012 & 0.003 \\
& $(0.88)$ & $(0.79)$ & $(0.17)$ \\
$\Delta \log (C P I)$ & 1.259 & 1.432 & 0.631 \\
& $(0.96)$ & $(0.95)$ & $(0.32)$ \\
Intercept & $0.067^{* * *}$ & $0.220^{* * *}$ & $-0.055^{* * *}$ \\
& $(6.91)$ & $(19.91)$ & $(-3.75)$ \\
\hline \hline & 2008 All & 2008 Short & 2008 Long \\
\hline$\Delta U_{t}$ & $-0.021^{*}$ & -0.021 & -0.014 \\
& $(-1.93)$ & $(-1.7)$ & $(-0.71)$ \\
$\Delta \log (C P I)$ & 1.536 & 1.632 & -3.491 \\
& $(1.15)$ & $(1.1)$ & $(-0.95)$ \\
Intercept & $0.035^{* *}$ & $0.078^{* * *}$ & 0.008 \\
& $(2.59)$ & $(5.27)$ & $(0.32)$ \\
\hline \multirow{4}{*}{} & & &
\end{tabular}

